\title{
Critical Spaces of Diaspora and the Shifting of Paradigm: Negotiating Intercultural Narratives in Arab Anglophone Literatures
}

\begin{abstract}
Ayman Abu-Shomar ${ }^{1}$
${ }^{1}$ The University of Jordan/ Aqaba, Faculty of Languages, English Department

Abstract: The last few years have revealed a resurgence of interest in questioning the orthodox consensus regarding what has been so far believed to be a grounded paradigm of Arab-Western relations. Recently, these relations have become labyrinthine in nature inviting us to 'stop and think' of the towering socio-political and cultural contingencies involved in this encounter. The aftermath of the 'Arab Spring', in particular, has imposed paradigmatic socio-political shifts for both Arab and Western societies including massive waves of migration to the West prompting fragmentation and growing pluralism of these societies and emergence of new identities, but also new forms of conflicts, which render normative and stable discourses problematic. This requires growing demands of ever-changing needs to the insurgency and disintegration of moral obligations while negotiating with difference, hence, refusing polarising tendencies historically shaping Arab-Western intercultural encounters. For this, the adoption of the healing power of dialogism informed by 'critical spaces of diaspora' provides a rethinking-space for Arab Anglophone writers to capture the multitude of these new conditions. This essay attempts to trace the performance of this dialogic tendency as a key feature in intercultural narratives adopted by several Arab Anglophone writers. With the claim that both 'cultural compatibility' and 'clash of civilization' narratives fail to capture the current nature of the Western-Arab encounters, this essay seeks to foreground and theorise a third and a 'not-yet-told' narrative to reinstate critical cultural awareness as an antidote to dualistic tendencies
\end{abstract}

Keywords: Diaspora, dialogism, Intercultural Discourse, Arab/Western encounters, Arab Anglophone Writers

In the last decade, Arab Anglophone literature has received a growing attention and interest of readers, critics and publishers who collectively refer to as 'minority literature'. With the growing pluralism of literature carrying this category, the label itself becomes insufficient to capture the multitude of literature produced by those writers. But quantifying is not my concern in this paper, it is rather the voice, or the polyphonic voice, to use Bakhtin's terms, which features the majority of Arab Anglophone narratives. I also make a point of departure from Deleuze and Guattari's conceptualisation of those literatures as representing minor borderland narratives; a theme that is also rehearsed by Geoffrey Nash's through his categorisation of those writers as "Third World subaltern women". Although other categorisations including Anglophone or hybrid have also found their places in the nomenclature of critics attempting to establish distinct identification to those writers, these references remain subdued reactionary appellations to a mainstream tradition. To me, this categorisation is deeply engraved in an epistemic tendency that still bears the genealogy of the Hegelian, dualistic or binary logic of making meanings. To barrow an argument from Said, there always exists a point of reference through which the 'Other' is known, labelled and understood. Arab Anglophone as minority literature is thus a notion branded in reference to Anglo-American tradition; a 'self'-tradition recognised in the vocabulary of publishers and appropriated through the majority of Western critical receptions. In short, the cluster of concepts including 'minority', 'subaltern' and 'hybrid' literatures instigate a critical tradition that is originated in the 'centre- 
periphery' epistemology. In short, it is quite possible to claim that Arab Diaspora or Anglophone literature is still in the embryonic stages of theorisation.

Rethinking the conditions of Arab Anglophone literature beyond such binaries requires broadening our perspectives to include not only the intrinsic elements of those literatures but also their "worldliness" represented by socio-political, critical and cultural contexts and dynamics. The stated mission of this paper is a prima face simple and direct one: with the emergence of an invisible but influential new paradigm in intercultural narratives, the old dichotomies of us versus them are no longer valid to capture the socio-political status neither for those writers nor for their thematic concerns. Historically, as Abdul Aziz Said and Nathan Funk observe, two distinct intercultural narratives that might capture the relationship between Islam and the West: "incompatibility" of "cultures", (or "clash of civilization" as Samuel Huntington puts it, and the "compatibility" narrative calling for "coexistence" between the two cultures. In their exploration of those narratives, Said and Funk argue: "such narratives provide authoritative, common sense understandings about the nature of perceived threats to the group and its values" (3). They describe those narratives as essentially exclusive adopting "defining boundaries", while the discourse of the incompatibility narrative is armed by protracted historical conflicts, the "compatibility story", which has been dissatisfactory, kept itself busy finding common roots between those two cultures. Although proponents of the two approaches adopt two distinct agendas, they endeavour a similar epistemic stance of reading the current postmodern stance of the two cultures. In response, I draw on "ethnological imagination" embedded in "symbolic anthropology" that adopts radical hermeneutics for its empiricism. This conceptual tendency, according to Fuyuki Kurasawa, enables a dynamic distinction through both "involvement" and "detachment". While "involved critique employs another state as a normative guide to make sense of, and even possibly change, the existing social order [...], detachment, by contrast, aims to achieve a certain distance from one's social context, either historically, culturally, or in both manners" (13). Radical hermeneutics, among other similar critical tendencies, enable a detached critique responding to both historical (genealogical) and intercultural (ethnological) perception of the contemporary human conditions.

Recognising the emergence of such a new socio-cultural paradigm, a growing number of intellectuals have kept themselves busy finding new language while deeply criticising the former polarising tendencies historically shaping intercultural narratives between Islam and the West. With special focus on the thesis of "clash of civilisation", Cohen criticises dualistic approaches to those narratives, which ignore the cataclysm of sociocultural shifts in contemporary status of Western societies. He argues: "it is common to find assertions and extremist attitudes in the face of subterranean shift of reality ... by contrast, we easily miss subtle, discreet but undeclared social changes that slowly but cumulatively generate major shifts in social conduct, opinions and consciousness" (2). For him, the Jihad vs. McWorld classificatory paradigm, historically standing against each other, misses the fact that culture is travelling via what he refers to as "creolisation". Creolisation, he proceeds, is an invisible but influential emerging paradigm operating through "the formation of new identities", which are "subversive of race and ethnicity" (5). He argues that beneath the loud and monstrous voices of nationalism lie pervasive voices of diversity and complexity. Likewise, Zygmunt Bauman's Culture in a Liquid Modern World departs any sense of pure and authentic understanding of culture. Bill Ashcroft's Beyond the Nation: PostColonial Hope talks about the long-lasting scene of culture-in-translation, the moment of 'betweenness' through which the current subjects of the human conditions are constituted: "it is the 'inter" - the cutting edge of translation and renegotiation, the in-between space - that carries the burden of the meaning of culture" (p. 14). Dalai conceptualises any meaning of culture not as an authoritative end, but rather as an ongoing and becoming, and as a continuous process with heteroglossic and polyphonic implications and intentions. Last, Clifford claims that 'dwelling-in-travel' forces us to rethink the rubric of our old concepts, monolithic discourse and epistemologies.

Critical Spaces of Diaspora - a thesis that I have proposed and rehearsed in several studies - offers a further engagement and conceptualisation of intercultural narratives within the rubrics of diaspora studies and critical 
thought. In the last few decades, concepts such ad 'third spaces', 'in-between', 'cross-culturalism', 'cultural diversity', 'pluralism' and 'hybridity' among several others have inspired scholars to discern the meaning of such an inevitable socio-political shifts in Western societies. Intellectual and theoretical engagements with former and contemporary intercultural narratives are voluminous pertaining to what have become among the most contestable concepts of our times including three umbrella terms: post-modernity, post-coloniality, and liquidity (after Bauman, (2000)).

The notion of Diasporas, which has been an offshoot of diasporic experience, mounts up as another major source socio-cultural for empirical knowledge alongside with these theories and concepts. Since their conditions, knowledge and perceptions of identity flow across national and transnational boundaries, it is believed that the people of diaspora, in general, and writers, in particular, have developed a sort of diasporic ontological and epistemological existence that enables them to surpass 'all-home-returning projects' and pleas for pure identity. They negotiate the complexities of difference in the new cultural spaces which open up between familiar and foreign meanings, relations, and identities. The status of writers of diaspora necessitates a double amenity for the possibility of freedom from the ontological constraint of 'culture' as they behold two worlds in front of them: that of diaspora and that of imagination. Ashcroft (2009), after Said, discusses the utopian tendency in postcolonial criticism referring to this condition as 'freedom from identify itself' in addition to the constriction of national borders. As Maniam (quoted in Dalai, 2008) declares, "to understand the symbiosis between diasporic experience and the literature that grows in it, literature becomes a 'device to decode the epistemology of diaspora" (p. 8). Thus, diasporic literary experience appropriates 'reality' not as an authoritative end, but rather as an ongoing and becoming, and as a continuous process with heteroglossic and polyphonic implications and intentions (Dalai, 2008).

Three major segments could be inferred from the banner Critical Spaces of Diaspora embraces: Diasporic Epistemology, the Diasporic literary text and the current condition of post-coloniality. Within the critical epistemological paradigm, diasporic spaces become an antidote to monolithic ethnocentrisms, culturally informed knowledge and essentialism. As Dalai (2008) contends: "One among several enigmatic epistemologies of our times is diaspora. It is a complex, constant and constitutive aspect of human life (more so in our time) since the inception of modernity, through colonisation till the recent phenomenon of globalisation" (p. 8). I wish to highlight three words: complex, constant and constitutive in Dalai's readings of diaspora as backdrop thrusts into my discussion of the Epistemology of Diaspora that informs the theme of Critical Spaces of Diaspora. Diaspora(s) are labyrinthine in nature including discursively constructed and mobilised identities, and their multifaceted manifestations, narrative and dialogic engagements located in-between spaces qualify corrective locale to ethnocentric cultural discourses and work as antidote against the 'violence' and monolith of modernist certainties. They diffuse our critical demeanours through their hybrid and fragmented identities, which renders the multiplicity, mobility and dynamicity of epistemologies not only conceivable but also inevitable. The creation of diasporic spaces allows creative improvisation as non-finite and dynamic locales for not only negotiating with difference but also challenging the notions 'self' and 'otherness'. The notion of diaspora needs to be complicated as it entails amalgamation of dispersion, memories, myths, alienation, nomadism, ongoing and hybrid identities, complex histories of dwelling, and travelling, or in Clifford's words (1997), 'dwelling-intravel' - all of which force us to rethink the rubric of our old concepts, monolithic discourse and epistemologies. The complexity and dynamicity of the concept remind us of Brubaker's (2005) argument in his 'The 'Diaspora' diaspora' perceiving that the notion of diaspora has been stretched out in various directions including its semantic, conceptual and disciplinary spaces. As such, the notion has become to entail confluence and convergence of multiple ideas, meanings, cultures, experiences, which offer myriad, dislocated sites of contestation to the hegemonic and homogenising forces (Brazial and Mannur, 2003).

Post-colonialism and diaspora are inextricably interconnected within the context of literary studies. The theoretical innovations of Edward Said, Homi Bhabha, Gayatri Spivak, Stuart Hall, Paul Gilroy, James Clifford 
and others have in recent years vitalised postcolonial and diaspora studies, challenging ways in which we understand 'culture' and developing new ways of thinking beyond the confines of the nation state. The notion of diaspora has been productive in its attention to the production of new forms of knowledge and discourse, whether these discourses are produced in 'the host-land', in the transitional spaces of cultures or absorbed by people at 'home'. But perhaps for even greater significance to the current intercultural narratives, a consideration of the epistemological implications of the term - diaspora requires more theorisation. Such studies see migrancy in terms of adaptation and construction - adaptation to changes, dislocations and transformations, and the construction of new forms of knowledge and ways of seeing the world. Recurrently, the proliferation of epistemologies has been espoused into understanding the surge of the emergent postmodern condition, which is not simply academic in fashion but rather a response to substantive changes in the way we perceive our condition form the most private and intimate to the most exoteric and global.

In literary and cultural studies, diasporic studies have been a well-established paradigm as appears the extensive writing of famous cultural and literary theorists such as Bhabha's: 'Hybridity' and 'Thirds Space' (1994, 1996); Hall's (1996a) and Gilroy's (1997) Hybrid identities, among others. A common theme for those critics is the exploration of the complex fabric of diaspora within the notions of Hybridity, culture-in-between, cultural difference and multiculturalism. Reflecting on the role of those border-crossing theorists and artists who write outside the 'nation-state' borders, I favour Sehyan's observation that "every theory of postcolonial, transitional, or diasporic literature and art is most convincingly articulate and performed by works of literature and art themselves" ( $p$ 36). With the emergence of "literature as social practice" (Eagleton, 2011), the role of readers who engage with literary meanings and interpretations has become very much like agents who turn to literature to help them in larger purposes in life, such as reflecting on their identities and possibilities for moral and emotional engagements (Hall, 2005).

Additionally, diasporic writers such as V. S. Naipual, K. S. Maniam, S. Nadan and S. Rushdie have touched the complexity of meanings in their diasporic texts. For example, in his 'Imaginary Homelands: Essays and Criticism', Rushdie (1991) perceives meaning as "a shaky edifice we build out of scraps, dogmas, childhood injuries, newspaper articles, chance remarks, old films, small victories, people hated, people loved; perhaps it is because our sense of what is the case is constructed from such inadequate materials that we defend it so fiercely, even to death" (p. 73). Maniam (1987) perceives the intersection of diaspora and literature a powerful apparatus to discover the power of the text to decode the epistemology of diaspora. For him, fiction has been the exploration of the past, present, psychology, conflicts and ambitions of Indian diaspora in Malaysia (p. 218). Similarly, Nadan (2000) perceives diaspora-writing as a venture not only to understand but also to survive: "it has become [...] not only the enigma of survival, but a way into the world, a solid mandala. Writing, though fragile and vulnerable, is the only home possible" (p. 101). As Khorana (2009) contends: "diasporic texts remain coherent representation of the lives of diasporas, as well as of the global-local nuances of the transitional era.

Certainly, Anglophone Arab literature falls in the diaspora studies paradigm producing complex, mosaic, dialogic and peculiar thematic concerns. This proliferated tendency has created lack of consensus among critics to find theoretical frameworks under which those writers can be classified. In addition to the collective name of 'minority writers', other names such as non-native, feminist (for women writers), etc. What has been problematic is which the announced literary frameworks best epitomise those narratives and how to categorise this complexity of a literary trend. Critical Spaces of diaspora, in the manner described above, responds to this complexity for the following reasons. First, while Arab Anglophone narratives are widely divergent in terms of their cultural, political and religious heterogeneity, they share on one common ground that is they are all diaspora writers who live in country other than what is commonly referred to as homeland. In this, diaspora makes a collective impetus) through which those writers articulate, and to far extend negotiate issues such as displacement, hybridity, double consciousness, homelessness, etc. Diaspora as a locus of enunciation removes culturally and ideologically informed agendas, and enables new epistemological outlets constructed through 
dialogic engagements, co-existence, tolerance as well as critical cultural understandings. Arab Diaspora writers including Leila Aboulela, Ahdaf Soueif, Fadia Faqir, Laila Lalami, Layla Halabi, Diana Abou Jaber, Susan Muddi Darraj among others - have established an innovative meaning of exilic consciousness mounting up as a productive identity crisis. For example, Aboulela's polyphonic novel The Translator creates such critical spaces to negotiate intercultural discourse through the autonomous voices of her characters (Abu-Shomar, 2019). Through the depiction of the love story of her protagonists Sammar and Rae, Aboulela produces a "romance narrative the breaks through the archetypical love romance of male dominance which prevailed in the colonial literary canon" (ibid, 5). At the same time, Aboulela frames her cross-cultural romance to dismantle the boundaries of the essentialist taboos of extreme Muslim traditions, which are not sanctioned by Islam itself. Similarly, Susan Darraj's The Inheritance of Exile produces an intercultural narrative that is grounded in Diasporic epistemology. Being bifurcated by two contradictory worlds, Palestine and America, the female protagonists develop a moral exilic consciousness that allows them to reconcile the antagonisms of the two worlds. In her commentary on those characters, Abu-Jaber explains, "The immigrant compresses time and space - starting out in one country and then very deliberately starting again, a little later, in another. It's a sort of fantasy - to have the chance to recreate yourself" (1).

In his memoir, Leave to Remain Abbas El-Zein, a Lebanese-Australian writer anchors the notions of home and dislocation while constructing diaspora as an emergent 'third space', which allows him to reconfigure the concept of home:

Home is a connection of physical and mental dwellings. I travel between them and live a virtual metropolis of my making. I am still very much part of my family in Lebanon and I now have a family and friends in Australia, and enough loyalty to call Australia home.

With such complexity and reconfiguration of home, writers create transnational loyalties that are circumscribed by specific geographical location, but rather without borders while adopting transnational imperatives. Similarly, Rabih Alameddine's novel I, the Divine mystifies the concept of home. His female protagonist evokes "whenever she is in Beirut, home is New York. Whenever she is in New York, home is Beirut. Home is never where she is, but where she is not" (99). Drawing on the above examples and many others, it can be concluded that diaspora is an antidote to all home returning projects while conceptualising bordercrossing as a consistent location mounting up as a home.

Secondly, Critical Spaces of diaspora features a polyphonic and dialogic voicedness rather than a monolithic or dualistic voice, and diaspora writers. Fictional narratives, as Bakhtin envisions, place the hero and the audience in creolized proximity to one another that replaces definitive judgments with mutual openness and responsiveness. Their new relationship to reality is however substantially changed into a "multi-toned narration" and "hetero-voiced nature". Bakhtin reasons: "alongside the representing word there appears the represented word; ... a leading role is played by the double-voiced word. And what appears here, as a result, is a radically new relationship to the word as the material of literature" (108). He concludes that such shifts posit the dialogic nature of truth, and the dialogic nature of human thinking about truth:

The dialogic means of seeking truth is counterposed to official monologism, which pretends to possess a ready-made truth, and it is also counterposed to the naive self-confidence of those people who think that they know something, that is, who think that they possess certain truths. Truth is not born nor is it to be found inside the head of an individual person, it is born between people collectively searching for truth, in the process of their dialogic interaction [emphasis is original]. (110)

Drawing on this outlook, the voices that Arab diaspora writers create in their fiction intermediates between multiple subject positions of their characters. This dialogic tendency is found in the majority of those writers. Since identity and voice are as much bound up with each other, those writers challenge predictable identityconstruction repertoires such as nationality and religion offering instead conflicting subject positions of characters belonging to similar religious or cultural backgrounds. In dialogic novels, as Bakhtin believes, the "world is profoundly personalized", in that every thought or idea is represented as a position of personality (9). 
In Aboulela's The Translator, Rae and Sammar, construct their personal as well as their professional identities via the evolution of dialogic intercultural discourse. Rae who is a "Middle-East" historian and a lecturer in "Third World" politics, refuses to be referred to as "Islamic expert" believing that this label conveys "much monolith" (7).

Thirdly, and last, diaspora writers develop a sense of humanistic outlook through which they unbind their narratives from ideologically informed meanings. For example Susan Abulhawa, an American-Palestinian writer, searches for the humanistic elements of all her characters both the Jews and Arabs. While she does not yield criticism to the Israeli occupation to Palestine and the trauma this occupation has created to three generations of Palestinian families, she splits the individual characters from their ideological background.

Critical Spaces of diaspora, to conclude, rejects essentialist 'belonging', purity and authenticity of culture. They emphasise the idea of metaphoric 'homelessness' as an escape of the pleas of 'self-evidence and 'authentic 'I". They become an inevitable 'in-between' position that rejects 'fixity', 'fetishism', and 'authenticity' of culture. They create a 'diasporic eternal-improviser is never a 'controlled individual' or being 'swallowed' by the 'system'. In their intention as critical 'stances' and resisting projects, both theories reject the doctrinaire of ideology, dogma, and ethnocentricity.

\section{References}

[1] Aboulela, Leila. The translator. Birlinn Ltd, 2015.

[2] Abu-Jaber, D. (2005). The Language of Baklava: A Memoir. New York: Anchor, 2006.

[3] Abu-Shomar, Ayman. "Critical Spaces of Diaspora for liquid post-modernity." Journal of Postcolonial Cultures and Societies 4, no. 3 (2013): 1-14.

[4] Abu-Shomar, Ayman. "Unreconciled Strivings of 'Exilic Consciousness': Critical Praxis of Resistance in Susan Abulhawa's Mornings in Jenin. Journal of Holy Land and Palestine Studies 18, no. 1 (2019): 101-120. https://doi.org/10.3366/hlps.2019.0204

[5] Abu-Shomar, Ayman. "Locating the Intercultural Discourse of Leila Aboulela's The Translator; Cultural Compatibility, Clash of Civilization or a Not-yet-told Story? Critique: Studies in Contemporary Fiction 61, no. 1 (2020): 52-66. https://doi.org/10.1080/00111619.2019.1645088

[6] Alameddine, Rabih. I, the Divine: A Novel in First Chapters. WW Norton \& Company, 2002.

[7] Ashcroft, Bill. "Beyond the nation: Post-colonial hope. The Journal of the European Association of Studies on Australia 1, no. 1 (2009): 12-22.

[8] Ashcroft, Bill. Caliban's voice: The transformation of English in post-colonial literatures. Routledge, 2009. https://doi.org/10.4324/9780203091050

[9] Bauman, Mark K. Dixie diaspora: an anthology of southern Jewish history. University Alabama Press, 2006.

[10] Bauman, Zygmunt. Culture in a liquid modern world. John Wiley \& Sons, 2013.

[11] Brubaker, Rogers. "The 'diaspora'diaspora." Ethnic and racial studies 28, no. 1 (2005): 1-19. https://doi.org/10.1080/0141987042000289997

[12] Bhabha, Homi K. The location of culture. routledge, 2012. https://doi.org/10.4324/9780203820551

[13] Clifford, James. "Diasporas." Cultural anthropology 9, no. 3 (1994): 302-338. https://doi.org/10.1525/can.1994.9.3.02a00040

[14] Clifford, James. The predicament of culture: Twentieth-century ethnography, literature, and art. Harvard University Press, 1988. 
https://doi.org/10.2307/j.ctvjf9x0h

[15] Cohen, Robin. Global diasporas: An introduction. Routledge, 2002.

https://doi.org/10.4324/9780203138762

[16] Dalai, P. (2006). Poetics Of Polyglossia In The Island Diaspora: A Reading Of K. S. Maniam's The Return.

[17] Deleuze, Gilles and Felix Guattari. Kafka: Toward a Minor Literature. Minneapolis, MN: University of Minnesota Press, 1986.

[18] Eagleton, Terry. Literary theory: An introduction. John Wiley \& Sons, 2011.

[19] El-Zein, Abbas. Leave to Remain: A Memoir. UQP, 2009.

[20] Evans, J., and Anita Mannur. "Nation, Migration, Globalization: Points of Contention in Diaspora Studies." Brazil JE, Mannur A.(a cura di), Theorizing aDiasporas, Oxford, Blackwell Publishing (2003).

[21] Gilroy, Paul. Diaspora and the Detours of Identity. Open University Press, 1997.

[22] Hall, Stuart, and Paul Du Gay, eds. Questions of Cultural Identity: SAGE Publications. Sage, 1996.

[23] Khorana, Sukhmani. "Diasporic art: writing/visualising back and writing/visualising into being." (2009): 453.

[24] Kurasawa, Fuyuki. "A cosmopolitanism from below: Alternative globalization and the creation of a solidarity without bounds." European Journal of Sociology/Archives européennes de sociologie 45, no. 2 (2004): 233-255. https://doi.org/10.1017/S0003975604001444

[25] Maniam, K (1996). The Return. Skoob Books Publishing.

[26] Muaddi Darraj, Susan. "The inheritance of exile." (2007). https://doi.org/10.2307/j.ctvpj79n9

[27] Nadan, S. (2000). Paradise in Pieces. Centre for Research in the New Literature in English.

[28] Nash, Geoffrey. The Anglo-Arab encounter: Fiction and autobiography by Arab writers in English. Peter Lang, 2007. https://doi.org/10.3726/978-3-0353-0419-0

[29] Rushdie, Salman. Imaginary homelands: Essays and criticism 1981-1991. Random House, 2012.

[30] Said, Abdul Aziz, Nathan C. Funk, and Ayse S. Kadayifci, eds. Peace and conflict resolution in Islam: precept and practice. Lanham, MD: University Press of America, 2001.

[31] Said, Edward W. The politics of dispossession: The struggle for Palestinian self-determination, 1969-1994. Vintage, 2012.

[32] Spivak, Gayatri. "Feminism and critical theory." Women's Studies International Quarterly 1, no. 3 (1978): 241-246. https://doi.org/10.1016/S0148-0685(78)90170-7 